\title{
EFEKTIVITAS LOGO TERAPI KELOMPOK DALAM MENURUNKAN GEJALA KECEMASAN PADA NARAPIDANA
}

\section{THE EFFECTIVENESS OF GROUP LOGOTHERAPY TO DECREASE ANXIETY SYMPTOM ON PRISONERS}

\author{
Hardiyanti Rahmah \\ Nida Hasanati \\ Program Magister Psikologi Profesi Universitas Muhammadiyah Malang \\ Email: rahmah.anwar@yahoo.co.id
}

\begin{abstract}
The aim of this study is to find out the effectiveness of group logotherapy in reducing prisoner anxiety symptom. There were five prisoners who will be free, but had an anxiety problem. They conducted group logotherapy that consist of six session treatments. Data was collected by interview, observation, and anxiety questioner HARS. Data analysis showed that anxiety, decrease after intervention was delivered.
\end{abstract}

Key words: group logotherapy, anxiety, prisoner

\section{ABSTRAK}

Penelitian ini bertujuan untuk mengetahui efektivitas logoterapi kelompok dalam mengurangi simptom kecemasan. Subjek kelompok merupakan narapidana yang sedang dalam proses persiapan pulang, namun merasa memiliki masalah kecemasan dalam menghadapi masa kebebasan mereka. Pengukuran data yang digunakan untuk mendiagnosa masalah kelompok adalah interview, observasi dan skala kecemasan HARS. Hasil dari intervensi ini menunjukkan adanya penurunan pada gejala kecemasan yang dialami kelima subjek setelah diberikan logoterapi kelompok.

Kata kunci : Logoterapi kelompok, gejala kecemasan, narapidana

Jumlah narapidana wanita kian bertambah dari waktu ke waktu. Di Lembaga Permasyarakatan Wanita kota M pada Tahun 2016 tercatat mencapai lebih dari 300 orang. Setiap individu yang dipidana sebagai pelanggar hukum mengalami perubahan status. Perubahan status yang dialami merupakan hal yang pasti. Sebelum masuk ke dalam lapas, para wanita ini berstatus bermacam-macam mulai dari ibu rumah tangga, pegawai, pedagang, mahasiswa dan sebagainya. Ketika masuk ke dalam lapas, maka statusnya berubah menjadi tahanan dan narapidana.

Selain status, hal lain yang berubah adalah pola hidup, yang dirasakan juga ikut berbeda dengan kehidupan di luar 
lapas. Sebelumnya individu dapat pergi ke mana saja dan berkumpul dengan keluarga, namun kini inidividu tidak dapat pergi ke mana pun dan tidak dapat berkumpul dengan keluarga. Perubahanperubahan yang terjadi secara tiba-tiba dalam hidup tersebut tentunya berdampak pada kondisi psikologis.

Status sebagai narapidana mengakibatkan seseorang menjadi malu dengan dirinya sendiri, dan juga menjadi sumber dari kekhawatiran, terlebih setelah bebas dari lembaga pemasyarakatan. Kekhawatiran tersebut berkaitan dengan penerimaan masyarakat terhadap diri individu sebagai mantan narapidana dan kekhawatiran jika dikucilkan oleh masyarakat.

Lamanya hukuman yang harus dijalani akan memengaruhikondisi fisik maupun psikologis seorang narapidana. Semakin lama masa hukuman yang harus dijalani oleh narapidana, maka semakin membuat individu beranggapan bahwa dirinya bukan bagian dari masyarakat. Munculnya anggapan seperti itu akan menyebabkan narapidan kesulitan dalam berbaur dilingkungan, dan membutuhkan waktu yang cenderung cukup lama untuk beradaptasi serta adanya perasaan kurang percaya diri dan memiliki harga diri yang rendah.

Kecemasan menjelang bebas pada narapidana muncul dikarenakan sejauh ini umumnya mantan narapidana masih dipandang negatif oleh masyarakat. Hal tersebut dapat menimbulkan kecemasan dan perasaan yang tidak nyaman bagi mantan narapidana pada masa setelah bebas. Narapidana tak jarang menjadi kehilangan rasa percaya diri dan jika dibiarkan berlarut-larut dapat menyebabkan munculnya gangguan-gangguan psikologis.

Berdasarkan penelitian yang telah dilakukan tentang kondisi narapidana di akhir masa tahanan, diketahui bahwa narapidana yang menjelang bebas akan mengalami kecemasan. Narapidana merasa cemas ketika menjelang bebas dikarenakan adanya keinginan dalam diri narapidana untuk segera bebas, tetapi kenyataannya stigma negatif pada mantan narapidana masih melekat di masyarakat. Akibatnya, masyarakat akan mengucilkan dan tidak akan percaya lagi. Penelitian memperlihatkan bahwa 38\% dari narapidana wanita yang menjelang bebas mengalami kecamasan berat, $34 \%$ mengalami kecemasan ringan, dan $28 \%$ mengalami kecemasan sedang (Utari, Fitria,\& Rafiyah 2011). Menurut penelitian yang dilakukan oleh Butler dkk (2005), sebanyak 36\% masalah kesehatan mental yang dirasakan oleh penguni lapas adalah kecemasan dan wanita lebih 
tinggi tingkat kejadiannya dibandingkan dengan pria, yaitu $61 \%: 39 \%$.

Para narapidana dengan masa tahanan yang hampir selesai di Lembaga Permasyarakatan Wanita (LPW) Kota M diketahui memiliki kecemasan-kecemasan dalam persiapannya menjelang bebas. Hal ini terlihat dari perilaku sehari-sehari dan perasaan yang dirasakan. Para narapidana merasa dirinya kecil, tidak berguna dan tidak bermanfaat bagi orang lain. Berdasar hasil dari skala kecemasan yang diberikan juga diketahui bahwa para narapidana memiliki kecemasan dalam kategori sedang.

Ketakutan-ketakutan dan kecemasan yang dirasakan seperti ketakutan tidak mendapatkan pekerjaan setelah keluar dari Lapas, cemas apabila tidak dapat diterima oleh keluarga, pandangan negatif masyarakat mengenai dirinya dan cemas apabila tidak dapat diterima oleh masyarakat.

Kecemasan dapat terjadi pada siapa saja termasuk pada warga binaan menjelang bebas di Lapas. Hal ini terkait stigma negatif sebagai mantan narapidana. Mantan narapidana saat ini masih dipandang negatif oleh masyarakat sehingga menimbulkan kecemasan, ketika narapidana sudah berada di luar lapas.

Kecemasan adalah suatu perasaan subjektif mengenai ketegangan mental yang menggelisahkan sebagai reaksi umum dari ketidakmampuan mengatasi suatu masalah atau tidak adanya rasa aman. Seseorang akan menderita kecemasan saat dia tidak mampu mengatasi stressor psikososial yang dihadapinya. Kecemasan yang berlebihan apalagi yang sudah menjadi gangguan akan menghambat fungsi seseorang dalam kehidupan. Dampak yang ditimbulkan dari kecemasan dapat mencakup fisik dan psikis (Shear, Bjelland, Beesdo, Gloster, \& Wittchen, 2007).

Kecemasan yang dirasakan oleh warga binaan meliputi kekhawatiran akan pandangan masyarakat terhadap seorang mantan narapidana dan peran menjadi seorang ibu bagi anak-anak, penerimaan anak terhadap seorang ibu mantan narapidana, peran seorang istri terhadap suami serta cemas menanti untuk bisa berkumpul bersama keluarga.

Berdasarkan hasil wawancara dan skala yang diberikan, didapatkan data bahwa kelima klien yang merupakan warga binaan mengeluh kesulitan tidur, sulit berkonsentrasi, kesulitan buang air besar, berdebar-debar, kehilangan selera makan, meluapkan emosi kepada orangorang terdekat serta marah tiba-tiba. Berdasarkan hasil observasi pada saat wawancara diketahui bahwa warga 
binaan terlihat gelisah, muka tegang, dan mudah menangis.

Munculnya kecemasan pada diri individu akan menyebabkan kondisi yang tidak nyaman bagi diri. Manusia pada umumnya memiliki kebebasan berkehendak (Nelson \& Jones, 2011). Manusia harusnya mampu merefleksikan dan menilai pilihannya, namun masalah akan muncul jika individu yang punya keinginan untuk kembali mencari makna dalam hidupnya, tetapi tidak punya kesempatan karena sudah merasa bahwa masyarakat tidak akan menerima individu kembali sebagai mantan narapidana.

Kehendak untuk menemukan makna pada manusia, menurut Frankl (Nelson \& Jones, 2011), adalah kekuatan motivational fundamental yang ada pada diri manusia itu sendiri, karena pencarian manusia akan makna adalah kekuatan utama dalam hidup. Salah satu alasan kenapa muncul perasaan cemas pada diri narapidana adalah adanya keinginan untuk menemukan makna pada diri individu sebagai alasan untuk hidup dan menjadi lebih baik, namun keinginan itu diiringi rasa takut saat berhadapan dengan sikap negatif masyarakat di luar sana

Menurut Frankl (Nelson \& Jones, 2011), setiap orang mempunyai pilihan dalam bagaimana merespon penderitaan. Sebagian orang bisa tetap tegak melawan tantangan penderitaan dan tumbuh lebih kaya dan kuat karenanya. Meskipun mungkin awalnya individu tidak memiliki daya, namun sebenarnya individu mampu menggunakan kebebasan batinnya untuk mengubah kesulitan menjadi prestasi.

Individu yang mampu merespon penderitaan yang telah dialaminya dengan lebih positif akan mudah memunculkan makna dalam hidupnya dan membantu untuk lebih positif saat menyikapi kehidupan yang akan dijalani selanjutnya. Individu yang sudah memiliki makna akan sadar terhadap tanggung jawab eksistensialnya, sehingga dia bisa mengembangkan potensinya dengan lebih baik tanpa ada rasa khawatir dan cemas terhadap pandangan negatif dari orang lain (Palmer, 2011).

Pada kelompok yang terdiri atas lima klien warga binaan ini, individu cenderung merespon penderitaan yang telah dialami secara negatif. Individu merasa memiliki banyak beban dan kesedihan ketika berada di penjara. Penderitaan-penderitaan itu juga akhirnya memunculkan rasa malu pada diri dan menjadi penyebab munculnya kecemasan ketika makin dekat waktunya untuk bebas dan selesai masa pidananya.

Salah satu intervensi kelompok yang bisa menjadi terapi untuk mengu- 
rangi kecemasan pada narapidana adalah logoterapi kelompok. Pendekatan pada logoterapi berpandangan bahwa makna hidup dan hasrat untuk hidup bermakna adalah motif asasi manusia yang dapat dilihat dalam dimensi spiritual (Nelson \& Jones, 2011; Morgan 2012).

Logoterapi memberikan cara bagaimana individu dapat memberi arti pada kehidupan dengan menciptakan sesuatu, dengan sesuatu yang diambil dari dunia dalam pengalaman, serta dengan sikap yang diambil dalam penderitaan. Pada logoterapi, klien dibantu untuk menemukan nilai-nilai baru dan mengembangkan filosofi konstruktif dalam kehidupannya. Klien bertanggungjawab pada dirinya sendiri dan logoterapi memberikan dorongan untuk memilih, mencari dan menemukan sendiri makna konkrit dari eksistensi pribadinya.

Dalam proses terapi, klien diperlihatkan bagaimana membuat hidup menjadi penuh arti dengan the experience of love. Pengalaman ini akan membuatnya mampu menikmati ketulusan, keindahan dan kebaikan serta mampu mengerti akan manusia dengan keunikankeunikan pribadinya. Dengan demikian, diharapkan klien dapat melihat bahwa penderitaan mungkin sangat berguna untuk membantunya dalam mengubah sikap hidup.
Logoterapi akan membantu klien untuk menghadapi kesukaran yang menakutkan atau berada dalam kondisi yang tidak memungkinkannya beraktivitas dan berkreativitas, dibantu untuk menemukan makna hidup dengan cara bagaimana individu menghadapi kondisi tersebut dan bagaimana individu mengatasi penderitaan. Dengan cara ini, klien dibantu untuk menggunakan kejengkelan dan penderitaannya sehari-hari sebagai alat untuk menemukan tujuan hidupnya.

Berdasarkan penjelasan di atas, dapat dirumuskan hipotesis bahwa logoterapi efektif dalam menurunkan gejala kecemasan pada narapidana.

\section{METODE PENELITIAN}

\section{Desain Penelitian}

Penelitian ini menggunakan desain penelitian kuasi eksperimen. Hanya ada satu kelompok pengukuran, yaitu kelompok eksperimen saja. Pengukuran dilakukan sebelum dan sesudah intervensi dalam bentuk one group pre-test post-test design, di mana pengukuran dilakukan berulang pada satu kelompok subjek yang sama (Kerlinger, 2006; Seniati, Yulianto \& Setiadi, 2011). 


\section{Subjek Penelitian}

Subjek penelitian dalam penelitian ini adalah orang narapidana dengan masa tahanan yang hampir selesai di Lembaga Permasyarakatan Wanita (LPW) Kota M yang menderita kecemasan. Jumlah subjek terdiri atas lima orang.

\section{Metode Pengumpulan Data}

Metode pengumpulan data yang digunakan dalam kasus ini adalah dengan menggunakan interview, observasi dan skala kecemasan yang dikembangkan oleh Hamilton untuk pertama kalinya (Hamilton 1959; Bjelland, 2002), yaitu Hamilton Rating Scale Anxiety (HARS). HARS digunakan untuk mengukur tingkat kecemasan pada orang dewasa yang mengalami gangguan kecemasan khususnya kecemasan sesaat (state anxiety). Skala HARS tidak diuji coba. Pertimbangannya adalah HARS telah terbukti memiliki koefisien validitas dan reliabilitas yang cukup tinggi yaitu 0,93 dan 0,97 . Artinya, skala HARS telah terbukti dapat mengukur tingkat kecemasan sesaat (state anxiety) secara valid.

\section{Prosedur Intervensi}

Intervensi yang diberikan dalam penelitian ini adalah logoterapi kelompok. Logoterapi berpendapat bahwa 'makna hidup' (the meaning of life) dan 'hasrat untuk hidup bermakna' (the will to meaning) merupakan motif asasi manusia yang dapat dilihat dalam dimensi spiritual. Frankl berpendapat bahwa ada dimensi lain selain dimensi somatik dan psikis, yaitu dimensi spiritual sebagai terapi untuk orang yang mengalami permasalahan psikologis (Nelson \& Jones, 2011; Morgan 2012).

Ada empat tahap utama didalam proses logoterapi kelompok. Pertama: Tahap perkenalan dan pembinaan rapport. Pada tahap ini diawali dengan menciptakan suasana nyaman untuk konsultasi dengan pembina rapport yang makin lama makin membuka peluang untuk sebuah encounter. Inti sebuah encounter adalah penghargaan kepada sesama manusia, ketulusan hati, dan pelayanan. Percakapan dalam tahap ini tak jarang memberikan efek terapi bagi klien.

Kedua: Tahap pengungkapan dan perumusan masalah. Pada tahap ini terapis mulai membuka dialog mengenai masalah yang dihadapi klien. Berbeda dengan terapi lain yang cenderung membiarkan klien "sepuasnya" mengungkapkan masalahnya, dalam logoterapi klien sejak awal diarahkan untuk menghadapi masalah itu sebagai kenyataan.

Ketiga: Pada tahap pembahasan bersama, terapis dan klien bersama-sama 
membahas dan menyamakan persepsi atas masalah yang dihadapi. Tujuannya untuk menemukan arti hidup sekalipun dalam penderitaan.

Keempat: Tahap evaluasi dan penyimpulan, yakni mencoba memberi interpretasi atas informasi yang diperoleh sebagai bahan untuk tahap selanjutnya, yaitu perubahan sikap dan perilaku klien. Pada tahap-tahap ini tercakup modifikasi sikap, orientasi terhadap makna hidup, penemuan dan pemenuhan makna, dan pengurangan gejala.

Teknik dalam logoterapi yang digunakan pada terapi ini adalah teknik paradoxical intention. Pada teknik paradoxical intention ini dilakukan dengan cara menekankan emosi (tidak nyaman) yang dialami oleh klien, agar klien tersebut sadar bahwa reaksi yang ditimbulkan oleh emosinya tersebut tidak rasional. Paradoxical intention pada dasarnya memanfaatkan kemampuan mengambil jarak dan kemampuan mengambil sikap terhadap kondisi diri sendiri dan lingkungan. Antisipasi yang menakutkan terhadap suatu kejadian sering menyebabkan reaksi-reaksi yang berkembang dari peristiwa tersebut. Dengan teknik paradoxical intention, inidivdu diajak untuk 'berhenti melawan', dan mencoba untuk 'bercanda' tentang gejala yang ada pada diri, ternyata hasilnya adalah gejala tersebut akan berkurang dan menghilang (Nelson \& Jones, 2011). Klien diminta untuk berpikir atau membayangkan hal-hal yang tidak menyenangkan, menakutkan, atau memalukan baginya. Dengan cara ini klien mengembangkan kemampuan untuk melawan ketakutannya, seperti yang terdapat juga dalam terapi perilaku.

Tahapan terapi terdiri atas praterapi, terapi, dan pascaterapi. (a) Praterapi. Pada tahap ini peneliti memberikan skala kecemasan pada narapidana di Lembaga Permasyarakatan Wanita di Kota Malang. Narapidana yang mendapat hasil skala dalam kategori sedang dipilih untuk menjadi anggota terapi kelompok. Selain itu dilakukan pembentukan kelompok untuk logoterapi kelompok (sesi 1) yang berlangsung 90 menit. (b) Tahap terapi. Tahap ini terdiri atas tahap eksplorasi, identifikasi dan modifikasi sikap, mengembangkan kemampuan dan eksplorasi harapan, membangun motivasi proyeksi terhadap nilai pribadi. (c) Pascaterapi. Pada sesi ini diberikan skala kecemasan (HARS) pada masing-masing anggota untuk melihat apakah ada perubahan setelah mengikuti terapi kelompok. 


\section{Teknik Analisis Data}

Teknik analisa data yang dipakai dalam penelitian ini menggunakan uji SPSS Nonparametrik. Uji nonparametrik dilakukan karena jumlah subjek dalam kelompok yang kurang dari 30. Bentuk data dalam penelitian ini berupa data ordinal, sehingga analisa statistik yang digunakan untuk melihat hasil pre tes dan post tes yaitu dengan uji Wilcoxon (Uyanto, 2009).

\section{HASIL PENELITIAN}

\section{Deskripsi Data Penelitian}

Berdasarkan tabel 1 dapat diketahui bahwa intervensi logoterapi kelompok yang dilakukan cukup efektif untuk menurun kecemasan pada para narapidana menjelang bebas. Ada penurunan tingkat kecemasan pada para narapidana tersebut, dari yang sebelumnya mengalami tingkat kecemasan yang tinggi, menjadi rendah.

Tabel 1.Perbandingan hasil prates dan pascates logotherapy

\begin{tabular}{llccccc}
\hline No & Nama & \multicolumn{2}{c}{ Prates } & \multicolumn{2}{c}{ Pascates } & Hasil \\
\cline { 3 - 6 } & & $\begin{array}{c}\text { Total } \\
\text { score }\end{array}$ & Kategori & $\begin{array}{c}\text { Total } \\
\text { score }\end{array}$ & Kategori & \\
\hline 1 & H K W & 42 & Tinggi & 15 & Sedang & Menurun \\
2 & M & 41 & Tinggi & 20 & Sedang & Menurun \\
3 & E S & 42 & Tinggi & 25 & Sedang & Menurun \\
4 & F F & 43 & Tinggi & 25 & Sedang & Menurun \\
5 & F A & 40 & Tinggi & 20 & Sedang & Menurun \\
\hline
\end{tabular}

Jika dilihat dari grafik 1 di bawah mengalami penurunan dari tingkat ini, maka dapat diketahui bahwa semua kecemasannya yang pada awalnya tinggi, subjek setelah mendapatkan terapi kemudian turun menjadi sedang. 


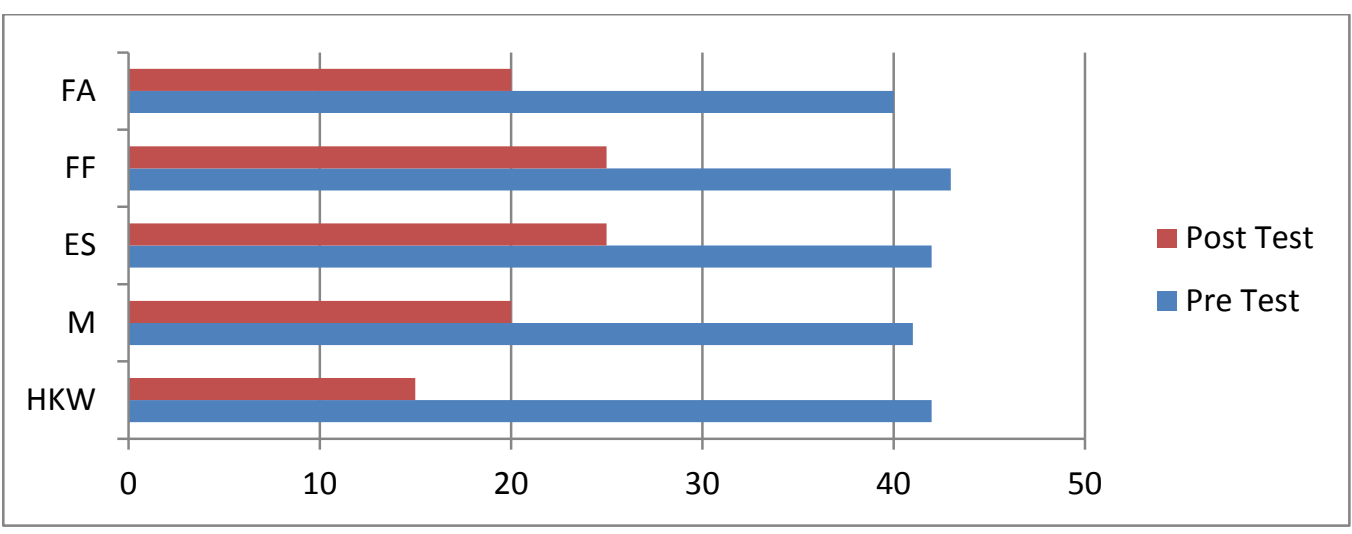

Grafik 1. Perubahan Sebelum dan Setelah Pemberian Logotherapy

Berdasarkan nilai pada tabel nilai rata-rata ini juga menunjukkan deskriptif statistik di bawah ini diketahui bahwa adanya penurunan tingkat bahwa nilai rata-rata hasil post tes lebih kecemasan pada narapidana. rendah daripada nilai prates. Maka hasil

Tabel 2. Descriptive Statistics

\begin{tabular}{lccccc}
\hline & & \multicolumn{3}{c}{ Std. } \\
& $N$ & Mean & Deviation & Minimum & Maximum \\
\hline Prates & 5 & 41.60 & 1.140 & 40 & 43 \\
Pascates & 5 & 21.00 & 4.183 & 15 & 25 \\
\hline
\end{tabular}

\section{Hasil Uji Hipotesis}

Berikut ini akan ditampilkan hasil analisis statistik.

Tabel 3. Test Statistics ${ }^{b}$

$\overline{\mathrm{Z}}-2.023^{\mathrm{a}}$

Asymp. Sig.

(2-tailed)

0.043

a. Based on positive ranks.

b. Wilcoxon Signed Ranks Test
Pada tabel dari hasil tes statistik, diketahui bahwa nilai signifikansi hasil prates dan pascates adalah 0,043 < 0,05 . Dengan demikian, dapat disimpulkan terdapat penurunan yang signifikan pada gejala kecemasan narapidana.

\section{Hasil Uji Kualitatif}

Selain dilihat dengan pengukuran dari skala HARS, perubahan setelah intervensi juga dapat dilihat dari sikap dan perilaku klien sehari-hari. 
Sebelumnya, kelima klien mengatakan sulit untuk tidur nyenyak karena mengalami kecemasan jika sedang melamun dan berandai-andai bagaimana saat pulang nanti. Sekarang mereka mulai bisa tidur dengan tenang, lebih sering tersenyum saat saling berbicara dengan sesama napi dan sudah jarang berkeringat jika memikirkaan ketakutanketakutan yang sering muncul di pikiran mereka.

Tabel 4. Perubahan Pemikiran dan Perilaku Narapidana Setelah Intervensi Logotherapy

\begin{tabular}{cll}
\hline No & \multicolumn{1}{c}{ Sebelum } & \multicolumn{1}{c}{ Sesudah } \\
\hline 1 & Tidak siap dengan status mantan & Para klien merasa yakin bahwa mantan \\
& narapidana yang akan disandangnya & narapidana bisa menjadi individu yang \\
& setelah keluar dari Lapas. & lebih baik. \\
2 & Merasa takut akan dikucilkan oleh & Para klien berpikir walaupun akan ada \\
& masyarakat setelah keluar dari Lapas & orang yang akan berbicara negatif \\
& & mengenai dirinya namun para klien \\
& & memilih untuk tidak mempedulikannya \\
& & dan akan membuktikan kepada orang \\
& & lain bahwa dirinya bisa sukses dan \\
& & menjadi baik.
\end{tabular}

3 Merasa tidak siap berinteraksi Para klien siap berinteraksi dengan dengan dunia luar karena merasa dunia di luar Lapas. tidak percaya diri dengan status yang disandangnya.

4 Takut tidak mendapat pekerjaan setelah keluar dari lapas

Apabila tidak mendapatkan pekerjaan setelah keluar dari lapas maka individu akan mencoba untuk membuka usaha sendiri dengan keahlian baru yang mereka miliki selama belajar di lapas (menjahit, merajut dan memasak) 
5 Merasa diri tidak berguna dan tidak

Para klien yakin bahwa dirinya adalah berharga lagi

manusia yang baik, dapat bermanfaat bagi orang lain dan bisa menjadi manusia yang sukses asalkan memiliki niat dan usaha yang kuat.

6 Sering merasa sulit tidur dan mudah Para klien sudah bisa tidur dengan terbangun di malam hari mudah dan jika terbangun saat malam individu akan shalat malam.

7 Sering berkeringat jika memikirkan Para klien sudah jarang berkeringat jika kecemasan-kecemasan dalam memikirkan apa dan bagaimana kondisi pikirannya dan sulit untuk tersenyum saat bebas dan saat berbicara dengan sesama narapidana mulai bisa tersenyum dan bercanda.

\section{PEMBAHASAN}

Berdasarkan hasil intervensi yang dilakukan, maka muncul perubahan pada semua klien, yaitu adanya penurunan tingkat kecemasan. Pada awalnya kelima narapidana memiliki tingkat kecemasan yang tinggi, namun setelah mengikuti logoterapi kelompok, maka narapidana yang awalnya berada pada tingkat kecemasan yang tinggi mengalami penurunan dan berada pada kategori stress sedang.

Penurunan tingkat kecemasan dari tinggi menjadi sedang dikarenakan proses dan intensitas pemberian logoterapi kelompok menjadikan anggota kelompok saling membantu untuk memotivasi masing-masing anggota di dalam kelom- pok intervensi. Hal ini membuat proses terapi berjalan cukup lancar dan hasil yang sesuai dengan harapan.

Logoterapi kelompok pada sebuah penelitian yang dilakukan di Filipina dapat membantu kelompok yang kehilangan makna dan tujuan hidup, kemudian saat diberikan logoterapi kelompok dapat meningkatkan kembali tujuan hidup mereka (Julom \& Guzman, 2013). Penelitian lain yang mengaplikasikan teknik logoterapi menunjukkan bahwa teknik logoterapi dapat membantu meningkatkan rasa eksistensial individu yang mengalami depresi bahkan trauma (Morgan, 2011; Hoaakazemi, Javid, Ebrahim, Tazekand, \& Khalili, 2012).

Teknik logoterapi cukup banyak diaplikasikan dalam berbagai kondisi, 
terutama untuk mengurangi rasa bersalah atau tekanan-tekanan dalam hidup lainnya yang dirasakan oleh sebagian individu, terutama bagi individu dengan status narapidana. Tekanan-tekanan yang muncul bisa mengakibatkan berbagai kondisi, salah satunya yaitu munculnya gejala kecemasan. Kecemasan yang merupakan gangguan mental cukup banyak terjadi di dalam LAPAS Wanita. Kecemasan yang meningkat merupakan efek dari hukuman yang diterima dari pengadilan karena melanggar hukum, selain itu juga dikarenakan stigma negatif dari masyarakat (Maryatun, 2009; Wijayanti, 2010).

Penelitian yang dilakukan di Lembaga Pemasyarakatan kota Semarang tentang teknik logoterapi untuk menurunkan tingkat kecemasan pada narapidana menunjukkan hasil yang sama dengan terapi yang dilakukan ini, yaitu adanya penurunan pada gejala kecemasan narapidana setelah mereka mendapatkan logoterapi kelompok (Wijayanti, 2010).

\section{SIMPULAN DAN SARAN}

\section{Simpulan}

Berdasarkan hasil asesmen menunjukkan bahwa kelima klien mengalami problem psikologis, yaitu tingginya tingkat lecemasan yang dimiliki oleh para klien. Untuk menangani problem tersebut terapis memberikan logoterapi kelompok dengan teknik intensi paradoksal untuk menurunkan tingkat kecemasan pada diri lima klien tersebut. Setelah memberikan logoterapi kelompok kepada klien, hasilnya menunjukkan perubahan yang baik. Sebelum mengikuti terapi hasil skala kecemasan kelima klien terletak pada level tinggi namun setelah mengikuti terapi hasil skala para klien menurun dan berada pada kategori sedang.

\section{Saran}

Rekomendasi untuk para subjek adalah para subjek dapat meningkatkan wawasannya terhadap apa saja yang bisa memunculkan gejala kecemasan, sehingga kemudian subjek dapat mengantisipasi munculnya tingkat kecemasan yang tinggi pada diri mereka. Rekomendasi untuk peneliti selanjutnya adalah berupaya agar dapat meningkatkan penerapan logoterapi baik kepada subjek individu atau kelompok dengan menggunakan dua atau lebih dari teknikteknik yang ada di dalam logoterapi. 


\section{DAFTAR PUSTAKA}

Bjelland, I. (2002). The validity of the hospital anxiety and depression scale. Psychosomatic Journal, 52, 2, 66-77.

Butler et al. 2005. Mental disorder in the New South Wales prisoner population. Australia : Justice Health, and University of New South Wales.

Hamilton, M. (1959). The assessment of anxiety states by rating. British Journal of Medical Psychology, 32, 50-55.

Hoaakazemi, M. S., Javid, M. M., Ebrahim, F., Tazekand, F. E. \& Khalili, S. (2012). The effect of logo therapy on improving the quality of life in girl students with PTSD. Life Science Journal, 9, 4, 5692-5698.

Julom, A. M. \& Guzman, R. (2013). The Effectiveness of Logotherapy Program in Alleviating the Sense of Meaninglessness of Paralyzed Inpatients. International Journal of Psychology \& Psychological Therapy, 13, 3, 357-371

Kerlinger, F. N. (2006). Asas-asas penelitian behavioral. (Terj.L.R. Simatupang). Jogjakarta: Gadjah Mada University Press
Maryatun, S. (2011). Pengaruh logoterapi terhadap perubahan harga diri narapidana perempuan dengan narkotika di lembaga pemasyarakatan klas 2A Palembang. Tesis. Universitas Indonesia. Depok.

Morgan, J. H. (2012). Geriatric logotherapy: Exploring the psychotherapeutics of memory in treating the elderly. Psychological Thought, 5, 2, 99-105. doi: 10.5964/psyct. v5i2.39.

Morgan, J. H. (2011). Late-life depression and the counseling agenda: exploring geriatric logotherapy as a treatment modality. International Journal Of Psychological Research, 6, 1, 94-101.

Nelson. R., \& Jones. (2011). Teori dan praktik konseling dan terapi. (pentrj. Helly Prajitno Soetjipto \& Sri Mulyantini Soetjipto). $\left(4^{\mathrm{ed}}\right)$. Yogyakarta: Pustaka Pelajar.

Palmer, S. (2011). Konseling dan Psikoterapi. Yogyakarta: Pustaka Pelajar.

Seniati, L., Yulianto, A. \& Setiadi, N. B. (2011). Psikologi Eksperimen. Indeks : Jakarta

Shear, M. K., Bjelland, I., Beesdo, K., Gloster, A. T. \& Wittchen, H. U. (2007). Supplementary dimensional assessment in anxiety disorders. 
International Journal of Methods in Psychiatric Research, 16, 1, 52-64.

Utari, D.I., Fitria, N \& Rafiyah, I. (2011). Gambaran tingkat kecemasan pada narapidana wanita menjelang bebas di Lembaga Pemasyarakatan Kelas II A Bandung. Jurnal Universitas Padjadjaran.
Uyanto, S. S. (2009). Pedoman analisa data dengan SPSS. Yogyakarta: Graha Ilmu.

Wijayanti, D. Y. (2010). The influence of logotherapy for female prisoner in female prison of semarang. Tesis. Universitas Indonesia. Depok. 